\title{
Development of TGT Cooperative Learning Model Based on Crossword Local Wisdom Educational Game in Kudus
}

\author{
Rochimah \\ \{ochisuwito@gmail.com\} \\ Master of Basic Education Study Program, Faculty of Teacher Training and Education, \\ Universitas Muria Kudus, Indonesia
}

\begin{abstract}
This study purpose to develop a TGT Cooperative Learning Model based on Crossword Local Wisdom Educational Game in fourth grade students of Primary Schools in Kudus. This type of research uses research and development methods (R\&D) which have been simplified into 8 steps. Data collection in this study was done by observation, interviews, questionnaires, documentation, and tests. This research was conducted in class IV SD 1 Gribig, SDIT Lukmanakim, and SD 1 Gamong. This development produces components, namely: 1) the syntax of the model; 2) social system; 3) The principle of reaction; 4) Support system; 5) Instructional impact and accompaniment impact. The results of the effectiveness test using Classroom Action Research (CAR), showed that there was an increase in learning aspects and skills. 1) Aspects of attitude, SD 1 Gribig and SDIT Lukman Hakim increased 91\% in cycle II. SD 1 Gamong increased in cycle II 89\%. 2) Knowledge aspects, SD 1 Gribig and SDIT Lukman Hakim, and SD 1 Gamong increased to in cycle II. 3) Aspects of skills, SDIT Lukman Hakim increased in cycle II 86. SD 1 Gribig cycle increased in cycle II 85. SD 1 Gamong increased in cycle II 83.
\end{abstract}

Keywords: TGT Learning Model, Local wisdom, Crossword

\section{INTRODUCTION}

Learning Model is a form of reaction between teacher and student to improve or develop themselves in learning activities. The Learning activities is a condition that is intentionally created by the teacher to provide knowledge and experience to students. There are several problems in education so far that might be considered very trivial namely a very ordinary learning model and less attractive to students. Based on the results pr observations and interviews in the three schools that will be studied obtained information that; 1) the teacher has not used the learning model to the fullest, 2) the teacher in teaching does not attract the attention of students, so students are partially unfocused, 3) the lack of introduction of Kudus local wisdom towards students, 4) student motivation to learn less passionate, and 5) lack of availability learning model books as reference material for teachers in teaching.

For this reason, researchers intend to use the TGT Cooperative Learning Model based on Crossword Local Wisdom Educational Game in Kudus district to improve teacher quality and student achievement. 


\section{LITERATURE REVIEW}

\subsection{TGT Learning Model}

TGT is a one type of cooperative learning. Is have five basic component. First class presentation second team, third game forth tournament fifth Team Recognition The main idea behind the model of TGT is to motivate students to encourage and assist one another tomaster the skills that are presented by the teacher. If students wish to gain appreciation of their group, they must help a group of friends to learn the materials provided. They should encourage friends to do the best and declare a norm that learning is an important, valuable and fun. According to Shoimin (2014) the model of TGT procedure are : 1.Group the students with each group consisting of three to five people. The member made the heterogeneous group includes the characteristics of intelligence, beginning math skills, learning motivation, gender, or different ethnic backgrounds.2.Learning activity begins with the presentation of teachers in explaining the lessons of exposure to the problem, providing data, giving example. Presented a goal is to introduce concepts and encourage student curiosity.3.Understanding of concept was done by students are given group tasks. They may do these tasks simultaneously or alternately with each other to ask the others or discuss the issue in a group or whatever it takes to master the subject matter. The students not required to fill out an answer sheet but also to learn the concept. Members of the group were told that they were considered not finished studying the matter until all group members understands the subject matter.

Students play academic games in the tournament weekly and friend group should not help each other. The game is intended to identify individual level mastery students to a concept in a way that students are given problem can be solved by applying the concept of a previously owned

\subsection{Kudus Local Wisdom Crossword Local Wisdom Educational Game}

A crossword word puzzleis a puzzle game which normally takes the form of a squareor a rectangulargridof white and black shaded squares. The goal is to fill the white squares with letters, forming words or phrases, by solving clues which lead to the answers. In languages that are written leftto-right, the answer words and phrases are placed in the grid from left to right and from top to bottom. The shaded squares are used to separate the words or phrases The writer conducted the research in SMPN 8 Bandar Lampung, because there is no research conducted there especially about the problem that was researcher observe. The writer has done the pre observation in SMPN 8 Bandar Lampung and put the focus on the second grade students. The puzzle gamesused inthis studyhas beenmatchedto thesecond gradelearning materials. The learning process showedthat some of students still passive in the class and feel shy to speak English because they have lack of vocabulary. This condition can be affect students' interaction in the class.

Local wisdom is basic knowledge gained from living in balance with nature. It is related to culture in the community which is accumulated and passed on. This wisdom can be both abstract and concrete, but the important characteristics are that it comes from experiences or truth gained from life. The wisdom from real experiences integrates the body, the spirit and the environment. It emphasizes respect for elders and their life experiences. Moreover, it values moral more than material things. (Nakorntap.et.al, 1996 in Roikhwanphut: 176). (Manugeren, 2017: 1) emphasizes that, Local wisdom is a set of ideas or polices based on the values of virtues found in a community and often applied, believed to be the guidance of life, and handed down from time to time. Based on the definitions, that local wisdom can be understood as a human effort by using their mind to act towards something, object, or events that occur in a certain space.

So We know that Crossword Local Wisdom Educational Game Crossword with local wisdom content:

\subsection{TGT Model Based On Crossword Local Wisdom Educational Game}

TGT have 5 component but in the reality teacher and student don't have antuciated to play the game in TGT because TGT Game have many difficulties regularement its make student have annoyed in learning activities. The Crossword Local Wisdom Educational Game aplyed in gema and tournament component in TGT. Local Wisdom Educational Game can improved TGT model be enjoyable learning 
model for teacher and student. with the aim of developing student creativity, so students can understand the material quickly and do assignments a lot of tasks easily. The form of learning implementation design using the TGT model based on the Kudus Local Wisdom is as follows:

1. Conveying the competencies to be achieved

2. To increase love dadn knowledge about Local Wisdom

3. Conveying concepts using images, video or original media

4. Forming discussion groups of 3-4 students (adjusting the number of students in one class);

5. Discuss according to submissions distributed by the teacher by noting alternative answers to the discussion.

6. Forming Team consist of different background student

7. Play the game with Crossword Local Wisdom Educational Game's

8. Play the tournament with Crossword Local Wisdom Educational Game's

9. Presentation in turn; included in Crossword Local Wisdom Educational Game's value because he had to be nice, read the results of his group, and be confident

10. Teacher give team recognition

\section{RESEARCH METHOD}

\subsection{Type of Research}

This type of research uses research and development methods or Research and Development (R\&D). Research and development or Research and Development (R\&D) is a research method used to produce certain products and test the effectiveness of these products (Sugiyono, 2015: 407). In this study, researchers developed the TGT Cooperative Learning Modelinto a model that produces interesting learning so that students are more interested in the learning process.

In this study, researchers used a development model according to Sugiyono, the development model of Borg and Gall (2015: 409). Research and development (R\&D) method can be simplified in the following steps: (1) potential and problems; (2) data collection; (3) product design; (4) design validation; (5) design revisions; (6) product trials; (7) product revisions; (8) trial use. Simplification of the steps in research and development is due to limited time, energy, and costs in research.

\subsection{Data Collection Techniques}

1. Observation Method, Observation as a data collection technique of teacher and student observation in learning mind Mapping models in class,

2. Interview Method, Structured and unstructured interviews conducted on teachers and students before the research and after the study.

3. Test Method, the purpose of using the test is to determine student achievement after studying the material through the Mind Mapping model based on the Holy Local Wisdom of Crossword Local Wisdom Educational Game in class IV.

4. Documentation Method, which is done at the time of documentation is to document photographs in learning according to the syntax, and documentation of the work results of student worksheets and test results.

5. Questionnaire, used to find out the analysis of the needs of teachers and students on the development of mind mapping models based on local wisdom Crossword Local Wisdom Educational Game.

\subsection{Data analysis of the Model Test phase}

To test the effectiveness of the development of this model, use Classroom Action

Research (CAR). Testing the effectiveness of learning through CAR can be done by measuring the increase in learning outcomes from pre-cycle, cycle I, and cycle II. If the 
learning outcomes in the second cycle are better or have increased from the first cycle, then the learning model developed is also declared effective.

\section{Research Results and Discussion}

\subsection{Attitude Aspects}

From the results of the effectiveness test, the average attitude aspects in the three elementary schools of research have reached the criteria of Very Good. Of the three elementary schools, the average student who reaches the criteria of Very Good at the end of the cycle is more than $80 \%$. The details are SD 1 Gribig in cycle I obtains an average of $86 \%$ and $91 \%$ in the second cycle, SDIT Lukman Hakim in the first cycle gets an average percentage of $84 \%$ and in the cycle gets an average percentage of $91 \%$. Whereas SD 1 Gamong in cycle I gained a percentage of $83 \%$ and in cycle II gained $89 \%$.

In line with Gusviani (2016), according to him, Indonesian human figures graduating from basic education should have the following characteristics: 1) Growing faith and piety towards God Almighty; 2) Growing ethical attitudes (polite and civilized); 3) Grow good reasoning (want to learn, want to know, enjoy reading, have innovation, take initiative and be responsible); 4) Grow communication / social skills (orderly, aware of the rules, can work together with friends, can compete); 5) Growing awareness to maintain a healthy body.

\subsection{Aspects of Knowledge}

\begin{tabular}{|c|c|c|c|c|c|c|c|c|c|c|}
\hline \multirow{4}{*}{ No } & \multirow{4}{*}{$\begin{array}{l}\text { The name of } \\
\text { School }\end{array}$} & \multicolumn{9}{|c|}{ Efectivity test } \\
\hline & & \multicolumn{3}{|c|}{ Cycle before } & \multicolumn{3}{|c|}{ cycle I } & \multicolumn{3}{|c|}{ cycle II } \\
\hline & & IPA & IPS & B. I & $\begin{array}{l}\text { IP } \\
\mathbf{A}\end{array}$ & IPS & B. I & $\begin{array}{l}\text { IP } \\
\text { A }\end{array}$ & $\begin{array}{l}\mathbf{I} \\
\mathbf{P}\end{array}$ & B. I \\
\hline & & & & & & & & & $\mathbf{S}$ & \\
\hline 1 & SD I Gribig & $61 \%$ & $\begin{array}{l}61 \\
\%\end{array}$ & $\begin{array}{l}53 \\
\%\end{array}$ & $\begin{array}{l}84 \\
\%\end{array}$ & $84 \%$ & $\begin{array}{l}79 \\
\%\end{array}$ & $\begin{array}{l}100 \\
\%\end{array}$ & $\begin{array}{l}89 \\
\%\end{array}$ & $\begin{array}{l}95 \\
\%\end{array}$ \\
\hline 2 & $\begin{array}{ll}\text { SDIT Lukman } \\
\text { Hakim }\end{array}$ & $65 \%$ & $\begin{array}{l}65 \\
\%\end{array}$ & $\begin{array}{l}61 \\
\%\end{array}$ & $\begin{array}{l}76 \\
\%\end{array}$ & $83 \%$ & $\begin{array}{l}70 \\
\%\end{array}$ & $\begin{array}{l}100 \\
\%\end{array}$ & $\begin{array}{l}78 \\
\%\end{array}$ & $\begin{array}{l}98 \\
\%\end{array}$ \\
\hline 3 & SD 1 Gamong & $47 \%$ & $\begin{array}{l}47 \\
\%\end{array}$ & $\begin{array}{l}41 \\
\%\end{array}$ & $\begin{array}{l}82 \\
\%\end{array}$ & $82 \%$ & $\begin{array}{l}76 \\
\%\end{array}$ & $\begin{array}{l}100 \\
\%\end{array}$ & $\begin{array}{l}76 \\
\%\end{array}$ & $\begin{array}{l}88 \\
\%\end{array}$ \\
\hline
\end{tabular}

From the results of the effectiveness test, the average classical completeness of pre-cycle, cycle I and cycle II has increased very well. At the end of the second cycle the classical completeness of students in three elementary schools was already quite high, namely above $85 \%$ with KKM 75. SD 1 Gribig with the number of students 38 got the results of classical completeness in IPS in cycle I by $84 \%$ and increased in cycle II with a percentage of $100 \%$ which means all students have completed. While the content of Indonesian language lessons in the first cycle got a $79 \%$ percentage and increased in the second cycle to $92 \%$ with three children who have not yet completed the KKM. Furthermore, from SDIT Lukman Al Hakim with the number of students 23 students get the results of classical completeness in the content of IPS lessons in cycle I with a percentage of $83 \%$ and an increase in cycle II of $100 \%$ which means all students are complete. While the content of Indonesian language lessons in cycle I received a percentage of $78 \%$ and increased to $91 \%$ with two students who had not yet completed the KKM. Furthermore, the classical completeness results from Gamong Elementary School with a total of 17 students, has a percentage of IPS load in the first cycle of 
$82 \%$ and has increased to $100 \%$ which means all students are complete. While the content of the Indonesian language in the first cycle obtained a percentage of $76 \%$ and increased in the second cycle to $88 \%$ with two students not completing the KKM.

Based on the information above, it can be concluded that the classical completeness using the model based on the Local Wisdom of Kudus Crossword Local Wisdom Educational Game in class IV on theme 1 semester 1 The Beautifulness of Togetherness has increased in each cycle with the final acquisition in the second cycle is very high with a percentage in each school reaching more than $85 \%$. This is the same as stated by Kurniawati (2014) according to her class is superior to creativity and mastery learning with the results of classical learning completeness class.Base on the result of this research so we can conclude that TGT model base on TTS Local Wisdom is effective to aplyed in learning activities.

\subsection{Skills Aspects}

\begin{tabular}{|l|l|l|l|l|l|l|l|}
\hline \multirow{3}{*}{ No } & \multirow{3}{*}{ The Name Of School } & \multicolumn{2}{|l|}{ Skills Aspects average } \\
\cline { 3 - 8 } & & \multicolumn{2}{|l|}{ Cycle before } & \multicolumn{2}{l|}{ Cycle I } & \multicolumn{2}{l|}{ Cycle II } \\
\cline { 3 - 8 } & & IPSTS & BI & IPS & BI & $\begin{array}{l}\text { Local } \\
\text { S }\end{array}$ & BI \\
\hline 1 & SD 1 Gribig & 74 & 73 & 82 & 81 & 85 & 84 \\
\hline 2 & SDIT Lukman Hakim & 77 & 74 & 84 & 82 & 86 & 87 \\
\hline 3 & SD 1 Gamong & 72 & 73 & 82 & 81 & 83 & 82 \\
\hline
\end{tabular}

From the results of the effectiveness test, the average student skills from pre-cycle, cycle I, and cycle II have increased. SDIT Lukman Hakim led with the highest average, namely IPS lessons in cycle I gained 84 grades and increased in cycle II with a value of 86 , while Indonesian language lessons in cycle I scored 82 and in cycle II scored 87. Furthermore SD 1 Gribig on cycle I IPS lesson load got 82 and increased in cycle II to 85, while the load of Indonesian language lessons in cycle I got a score of 81 and increased in cycle II 84 . Finally SD 1 Gamong on the load of IPS cycle I got an average score of 82 and increased in cycle II to 83 , while the content of Indonesian language lessons in cycle I got a score of 81 and increased in cycle II to 82. Thus the researcher can conclude that the achievement of the skill scores is already High because all the average skill scores are above 80 . As written by Hartati (2017) with the title development of image-assisted mind mapping models to improve narrative essay writing skills of fifth grade students in Semarang, saying that by controlling the intelligence and early knowledge variables, the learning model with the image-assisted Mind Mapping model is more effective than lecture learning and discussion models in improving the narrative writing skills of fifth grade elementary school students.

\section{Conclusions and Suggestions}

\subsection{Conclusions}

1. The development of the TGT Cooperative Learning Modelbased on Crossword Local Wisdom Educational Game produced several components including: 1) the syntax of the model namely; 2) Social system; 3) The principle of reaction; 4) Support system; 5) Instructional impact and accompaniment impact. The model is also equipped with a Crossword Local Wisdom Educational Game-based local wisdom learning mind mapping learning guide model. The book components are as follows: 1) cover, 2) introduction, 3) 
theoretical foundation (Crossword Local Wisdom Educational Game TGT Cooperative Learning Modeland local wisdom), 4) concept of mind mapping model based on Crossword Local Wisdom Educational Game, 5) instructions for implementing mind mapping based on local wisdom Crossword Local Wisdom Educational Game, and 6) learning devices.

2. The resulting model is declared effective in elementary schools, especially in class IV. This is evidenced by an increase in learning outcomes in three elementary schools on aspects of attitude, knowledge, and skills.

\subsection{Suggestions}

1. For teachers as managers of learning it is recommended that the application of mind-based learning models based on local wisdom of Crossword Local Wisdom Educational Game is still conveyed to students for inculcation of character values that are Crossword Local Wisdom Educational Game concept.

2. For schools it is hoped that there will be efforts in the preservation of local wisdom in Kudus such as Crossword Local Wisdom Educational Game for its students, instilling a sense of pride and love for the environment and the region.

3. Students are expected to love, preserve, and understand the local wisdom that is around. 


\section{References}

Sadiman, Arief S. 2011. Model pembelajaran Pendidikan: Pengertian Pengembangan dan Pemanfaatan. Jakarta: Rajawali.

Setyowati, Dewi Liesnoor.,dkk. 2012. Kearifan lokal dalam dalam menjaga lingkungan perairan, kepulauan, dan pegunungan. Semarang : sanggar press.

Siregar, eveline, Nara Hartini. 2015. Teori belajar dan pembelajaran. Bogor : Galia Indonesia Solehan T.W, dkk. 2008. Pendidikan Bahasa Indonesia di SD. Jakarta: Universitas Terbuka

Sugiono. 2015. Metode Penelitian Pendidikan Pendekatan Kuantitatif, Kualitatif dan R\&D. Bandung: Alfabeta.

Suhartini. 2009. Kajian Kearifan Lokal Masyarakat Dalam Pengelolaan Sumberdaya Alam dan Lingkungan'. Makalah disajikan dalam Seminar Nasional Penelitian, Pendidikan, dan Penerapan MIPA, FAKULTAS MIPA, Universitas Negeri Yogyakarta, 16 Mei.

Sulistyorini, Model Pendidikan Islam, Yogyakarta: Teras, 2009, 11.

Tahan Uji.2015. "Model Pembelajaran Bahasa Arab di Pondok 